\title{
MARGINALISASI WANITA MADURA
}

Oleh: Eni Sugiarti

Dosen Jurusan Sejarah FIB UNAIR, Surabaya

\begin{abstract}
Abstrak
Marginarlisasi perempuan Madura berhubungan dengan kegagalan Program Keluarga Berencana khususnya di Desa Omben dan Le Pelle. Kegagalan bukan semata-mata kesalahan pelaksanaan program Keluarga Berencana. Dari aspek etnosains kegagalan disebabkan oleh perbedaan pandangan antara pemerintah dan masyarakat tentang Program Keluarga Berencana itu sendiri. Kesuksesan dan kegagalan Program Keluarga Berencana sangat berkaitan dengan kultur masyarakatnya.
\end{abstract}

\section{Latar Belakang Permasalahan}

Berawal dari sebuah pengalaman hidup penulis ditengah-tengah "masyarakat Madura " atau orangorang Madura yang ada di wilayah desa Omben maupun Le Pellle Berangkat dari adanya adanya kejadian penolakan masyarakat Banyuwulu untuk mengikuti program Keluarga Berencana. Menurut penuturan dari Bidan desa di Banyuwulu problem ini sudah lama berlangsung dan belum mendapat solusinya. Permasalahan Keluarga Berencana untuk beberapa hal merupakan hal yang sudah dapat diterima oleh masyarakat Indonesia secara umum apalagi pada masa Orde Baru yang sangat gencar mensukseskan program Keluarga Berencana. fenomena sosial yang dihadapi oleh penulis pada waktu itu sangat menarik untuk dikaji dengan menggunakan teroi dan konsep teori kebudayaan. Hal ini dikaitkan dengan permasalahan persepsi suatu masyarakat dalam mensikapi suatu fenomena social yang ada di sekeliling mereka.
Dalam penelitian ini kegagalan program Keluarga berencana berhubungan dengan adanya proses marginalisasi wanita Madura yang dalam beberapa hal mereka sebagai kelompok masyarakat yang termajinalisasi secara sosial. Implikasinya adalah adanya perbedaan hak dan kewajiban yang terbentuk secara sosial. Proses marginalisasi wanita Madura membentuk adanya pola-pola social yang termanifestasikan dalam bentuk sikap dan tingkah laku yang mereka wujudkan dalam kehidupan sehari-hari.

Apabila kita menengok di wilayahwilayah Madura dan juga wilayah lain yang mayoritas pendudukanya berasal dari etnis Madura seperti di Bondowoso, Situbondo dan lainnya program Keluarga Berencana banyak mengalami hambatan kalau tidak dikatakan mengalami kegagalan. Kegagalan ini tidak semata-mata karena program ini tidak menyentuh daerah-daerah "pedalaman" atau wilayah yang sulit untuk dijangkau ataupun bukan karena 
belum masuknya program ini di tengahtengah masyarakat ataupun kurangnnya tenaga kader yang menangani program di desa-desa tersebut. Ketidakmampuan secara ekonomi untuk ikut sebagai peserta program keluarga Berencana rupanya bukan sebagai satu faktor penyebab dari kegagalan ini, hal ini tidak relevan dengan kenyataan di lapangan dimana program Keluarga Berencana tersebut tidak dipungut biaya, kalaupun ada biaya yang harus dibayar misalnya untuk ikut program KB spiral seorang ibu akan mendapatkan suplai dana dari desa. Dari sudut yang berbeda penulis mencoba untuk melihat permasalahan yang ada di Omben dan Le Pelle dengan menggunakan pendekatan etnosains.

\section{Rumusan Masalah}

Tulisan ini akan mencoba menyoroti permasalahan Keluarga Berencana di Omben dan Le Pelle dari sudut etnoekologi, dengan pokok kajian yaitu bagaimana kondisi sosial masyarakat desa Omben dan Le Pelle yang akan dikaitkan dengan munculnya perspektif terhadap program Keluarga Berencana terutama dengan adanya proses marginalisasai wanita madura. Dalam permasalahan ini tentunya akan menyinggung tentang pandangan pemerintah terhadap program Keluarga Berencana. Permasalahan program Keluarga Berencana harus dapat menyentuh pada sendi-sendi budaya yang berkembang pada suatu masyarakat dan bukan semata-mata pelaksanaan teknis dan teori terhadap suatu program. Bagaimana suatu masyarakat dengan budaya mereka masing-masing memahami terhadap suatu fenomena social yang ada dihadapannya.

\section{Tujuan Penulisan}

Tulisan ini dimaksudkan memberikan suatu gambaran yang berbeda dalam mensikapi terhadap suatu problematika sosial yang berkembang dalam suatu masyarakat dengan lebih mendekatkan pada permasalahan pemahaman terhadap pengetahuan dan prinsip-prinsip, aturan, norma, yang secara sadar atau tidak yang ada didalam sebuah struktur social masyarakat yang akan mempengaruhi terhadap munculnya pola-pola sikap dan tingkah laku dalam menerima atau menolak suatu fenomena. Dengan demikian tujuan dari tulisan ini memberikan suatu gambaran tentang sudut suatu suku atau sekelompok masayarakat dalam hal ini masyarakat Desa Omben dan Le Pelle terhadap program Keluarga Berencana dengan menghubungkan pada adanya pola-pola di dalam masyarkat desa tersebut yang membangun tatananan social dalam bentuk marginalisasi terhadap wanita-wanita yang ada di desa tersebut.

\section{Kerangka Konsep}

Etnosains berasal dari kata ethnos dalam bahasa Yunani yang berarti bangsa dan kata scienta berasal dari bahasa Latin yang berarti pengetahuan ( Heddy, 2005: 30). Menurut Heddy Shri Ahimsa Putra yang merujuk pada pendapat Sturtevart (1991) bahwa etnosains kurang lebih berarti pengetahuan yang dimiliki oleh suatu bangsa atau lebih atau lebih tepatnya lagi satu suku bangsa atau kelompok social tertentu. Dalam penjelasannya Sturtevart mendefinisikan etnosains sebagai "system of knwolegde and cognitions of a given culture"Sturtevart menekankan pada system dan perangkat pengetahuan, yang 
merupakan pengetahuan yang khas dari suatu masyarakat,karena berbeda dengan pengetahuan masyarakat yang lain ( Heddy, 2005: 30).

Lebih lanjut Heddy menjelaskan bahwa sebagai sebuah kajian antropologi ,paradigma etnosains bertujuan untuk mengetahui paling tidak ada tiga pusat kajian yaitu pertama, etnosains memusatkan perhatian pada kebudayaan yang didefinisikan sebagai the forms of things that people have in mind, their models for perceiving, yang dalam hal ini ditafsirkan sebagai modelmodel untuk mengklasifikasikan lingkungan atau situasi social yang dihadapi. Penelitian etnosains dalam kajian ini bertujuan untuk mengetahui gejala-gejala materi yang dianggap penting oleh suatu kebudayaan dan bagaimana mereka mengorganisir berbagai gejala tersebut dalam system pengetahuan mereka.apabila gejalagejala materi dapat diketahui maka akan dapat terungkap berbagai prinsip yang mereka gunakan untuk memahami suatu lingkungan dan situasi yang dihadapi, yang menjadi landasan bagi tingkah laku mereka disadur dari Tyler ( Heddy, 2005: 32 ).

Frake lebih lanjut menyebutkan bahwa pada setiap masyarakat, suku bangsa atau kelompok social tertentu pada dasarnya membuat klasifikasi yang berbeda atas lingkungan yang sama. Dengan mengetahui klasifikasi dan pengkatagorian dari berbagai macam gejala social dalam lingkungan ini akan dapat diketahui juga peta kognitif dunia dari suatu masyarakat tertentu ( Frake dalam Haddy, 2005: 32 ). Dalam kajian ini peneliti berusaha mengungkap struktur-struktur yang digunakan untuk mengklasifikasi lingkungan, baik fisik maupun social.
Kajian yang kedua, mengarahkan pada kajian yang lebih difokuskan pada kebudayaan sebagai "whatever it is one has to know or believe in order to operete in a manner acceptable to its members", atau hal-hal yang harus diketahui oleh seseorang agar dia dapat mewujudkan perilaku atau melakukan sesuatu dengan cara yang dapat diterima oleh pendukung kebudayaan tersebut. Kajian budaya difokuskan pada cara-cara, aturan-aturan, normanorma , nilai-nilai yang membolehkan atau sebaliknya yang melarang, serta mengarahkan atau menunjukan suatu hal.

Kajian ketiga memusatkan pada perhatian kebudayaan sebagai " a set of principles for creating dramas, for writing scripts, and of course, for recruiting player and audiences" atau seperangkat prinsip-prinsip untuk menciptakan , membangun peristiwa, untuk mengumpulkan individu-individu atau orang banyak.

Dalam kajian ini penelitian akan difokuskan pada prinsip-prinsip yang mendasari berbagai macam kegiatan dalam kehidupan sehari-hari sebagai upaya untuk memahami struktur yang tidak disadari dan berada pada tataran nirsadar namun mempengaruhi atau menentukan perwujudan perilaku dan tindakan sehari-hari.

Etnosains bertujuan untuk mendeskripsikan , melukiskan pengetahuan yang dimiliki oleh suatu masyarakat, suku bangsa atau kelompok social tertentu mengenai salah satu bagian atau unsure dari lingkungnnya.

Perbedaaan gender (gender differences ) yang dinyatakan oleh Ann Oakley dalam buku Sex, Gender and Society bahwa gender differences manusia antara laki-laki dan perempuan 
terjadi melalui proses yang panjang. Terjadinya perbedaan gender melalui saluran-saluran sosial dan kultural yang ada di dalam masyarakat. Perbedaan gender menjadi masalah saat salah satu pihak baik laki-laki maupun perempuan menjadi korban dari ketidakadilan karena perbedaan jenis kelamin ini. Perbedaan gender bukan mengacu pada adanya perbedaan sexual dalam arti perbedaan kodrati sebagi laki-laki dan perempuan. Perbedaan gender yang mengakibatkan adanya ketidakadilan diakibatkan karena perbedaan perilaku ( behavioral differnces ) antara laki-laki dan perempuan yang dikonstruksi secara sosial, yakni perbedaan yang diciptakan oleh oleh manusia melalui proses sosial dan kultural ( Fakih, 2001: $71)$.

Feminitas dan makulinitas merupakan bentuk sosial-budaya yang sama sekali bukan bawaan yang tidak dapat berubah dari waktu ke waktu, dari sebuah tempat ke tempat lain. Masalah feminitas dan maskulinitas akan mengikuti perkembangan penciptaan makna dari simbol maskulin dan feminim.

Adanya subordinasi yang dilekatkan pada diri seorang wanita menyebabkan perempuan membentuk kelompok-kelompok yang lemah. Subordinasi ini menyebabkan posisi wanita menjadi " seolah-olah "tidak penting dan perlu adanya penolong. Hal inilah yang seringkali menggiring wanita-wanita pada posisi-yang terpinggirkan dan dikatakan sebagi posisi yang secara sosial dirugikan. Wanita-wanita diposisikan sebagai kelompok yang tidak penting dan akan mengakibatkan marginalisasi peran seorang wanita dalam aspek-aspek kehidupannya.
Menurut Mansour Fakih, proses marginalisasi merupakan proses eksploitasi dalam bentuk pemiskinan atas jenis kelamin yang bersumber dari kebijakan pemerintah, tafsir agama , keyakinan, tradisi dan kebiasaan atau bahkan asumsi-asumsi dari ilmu pengetahuan. Lebih lanjut Fakih menggambarkan bentuk-bentuk marginalisasi terjadi dalam bentuk eksploitasi, pemiskinan,atau bentuk keterpinggiran lainnya ( fakih, 1997. hlm. 14 -15 ).

Pemusatan pada kegiatankegiatan yang ditujukan pada peran lakilaki ( androcentris ) dan wanita sebagai second sex merupakan sebuah penggambaran adanya perilaku sosial masyarakat yang secara sadar maupun tidak telah melakukan pengekploitasian dengan mengurangi peran yang sesungguhnya tanpa adanya pengakuan peran yang dijalankan oleh seorang perempuan. Marginalisasi menjadi hal yang dianggap wajar dalam sebuah masyarakat ( Kuntowijoyo, 2003:91113 ).

Berkaitan dengan masalah marginalisasi perempuan menurut Nunuk P. Murniati menyatakan bahwa sistem patriarkhi memberikan kecenderungan yang besar untuk terjadinya marginalisasi yang dialami perempuan. Seorang perempuan kan ditempatkan pada area pelayanan domestik rumah tangga dan adanya kodrat wanita untuk mengandung, melahirkan dan menyusui sehingga seorang wanita akan lebih baik ditempatkan pada posisi yang stabil di dalam rumah ( Murniati, 2005: 54).

Hal senada dengan dikatakan oleh Murniati tentang marginalisasi perempuan di kemukakan oleh Kuntjooroningrat bahwa proses marginalisasi perempuan dapat 
dilakukan dan dapat terjadi di dalam wilayah keluarga, rumah tangga atau dalam bentuk jaringan-jaringan sosial yang banyak melibatkan anggota masyarakat dalam sistem organisasi sosial yang berkembang. ( Kuntjoroningrat, 1998 : 54 ). Marginalisasi yang terjadi pada para perempuan dalam sebuah jaringanjaringan sosial dimana ketidakadilan tersosialisasi secara mantap dapa kaum laki-laki dan perempuan yang pada akhirnya perempuan menjadi terbiasa dan akhirnya dipercaya bahwa peran gender itu sebagai kodrat, dan akan tercipta struktur dan sistem ketidakadilan gender yang "diterima “ dan sudah tidak lagi dapat dirasakan ada sesuatu yang salah.

Wanita pada sistem patriarkhi ditempatkan sebagai objek oleh lakilaki. Dengan demikian dari banyak kasus tentang marginalisasi, posisi wanita selalu menjadi objek dari proses marginalisasi yang ada di dalam sebuah masyarakat ( Engineer, 2005: 97 ). Dominasi kekuasaan dan kekuatan lakilaki atas perempuan terjadi dalam segala aspek kehidupan politik, ekonomi, sosial budaya dan aspek-aspek lainnya. Dominasi laki-laki terhadap perempuan merupakan suatu hal yang mengakar kuat pada sistem patriarkhi yang berkembang pada sebuah masyarakat ( Muhadjir, 2001: 251-252 ).

Hubungan antara sistem patriarkhi dengan permasalahan perbedaan gender (gender differences) dikemukakan oleh Kamla Bashin yang menyatakan bahwa permasalahan perbedaaan jenis kelamin dalam sebuah sistem kekerabatan akan membawa konsekuensi pada munculnya perbedaan-perbedaan jenis hak dan kewajiban yang akan diterima dan dibebankan pada masing-masing jenis kelamin ( Bashin, 2003:3 )

Masalah analisis gender dalam tafsir agama menjadi suatu hal yang perlu dikaji dengan baik. Menurut Fakih ada kecederung dalam menafsirkan suatu ketidakadilan akibat gender dipengaruhi oleh pandangan-pandangan yang ada di dalam sistem patriarkhi sehingga menghasilkan suatu penafsiran tentang agama yang menempatkan dalam perspektif patriakhi juga sebagai contoh Tuhan " seolah-olah " sebagai sosok laki-laki (Fakih, 2001: 129-130).

\section{Tinjauan Pustaka}

Masri Singarimbun dalam tulisannya yang berjudul Keluarga Berencana Indonesia sampai Abad XXI: Beberapa Aspek Progrm dan Sosial Budaya menyinggung mengenai tumbuh dan berkembangnya program Keluarga Berencana dan mengapa program ini pada mulanya lebih ditujukan di daerah Jawa dan Madura. Masri juga memaparkan mulai dari munculnya program ini dan tujuan yang ingin dicapai oleh pemerintah yaitu adanya penekanan angka kelahiran. Beberapa kalangan masyarakat mempunyai pendapatnya dan mensikapi keberadaaan program ini. Bagaimana perpektif masyarakat yang bermacam-macam muncul dan bagaimana usaha pemerintah dalam hal memberikan penjelasan tentang program ini. Disamping itu pemerintah menjadikan program Keluarga Berencana sebagai salah satu program Pelita I 1969/70 - 1974/75 (Masri, 1988 :3).

Dalam sebuah makalah Masri Singarimbun yang berjudul Keluarga Berencana menjelaskan mengenai keragaman yang besar dalam program ini di negara-negara seperti 
Cina,Amerika utara, Jerman, Hongaria, Indonesia dengan memberikan suatu perbandingan yang dihubungkan dengan program pemerintah dan juga permasalahan perspektif masyarakat terhadap program ini. Di beberapa Negara yang dikemukakan Masri melihat adanya keberhasilan yang dicapai oleh pemerintah Indonesia terhadap program Keluarga Berencana, dengan mengedepankan peranan pemerintah dan juga adanya kemapanan struktur masyarakat yang sudah terbentuk sebelumnya serta pemanfaatan secara maksimal struktur ke bawah dalam masyarakat ( Masri , 1990 :1-7).

Salah satu hasil penelitian dari Proyek Penelitian Madura Depdikbud yang bekerjasama dengan Belanda tentang program Keluarga Berencana dan Kesehatan di Pulau Madura menyimpulkan bahwa program keluarga Berencana yang ada di Madura pada tahub 1977 masih memerlukan adanya penanganan yang serius hal tidak semata-mata pada permasalahan Materi dari program tersebut ada dalam penelitian tersebut dapat memetakan adanya beberapa factor yang berkaitan dengan kegagalan dan keberhasilan dari program keluarga Berencana di Madura. Namun demikian dalam hasil penelitian ini kurang menyoroti bagaimana perpektif masyarakat dalam konteks sebagai masyarakat budaya yang akan memberikan perspektif terhadap program Keluarga berencana, sehingga tulisan ini kurang melihat pemahaman masyarkat dalam konteks budaya sehingga factor pendukung dan penghambat dalam program ini seperti sebuah hal yang bersifat kausalitas saja dan kurang memberikan dapat mendeskriptifkan dalam perpsektif budaya masyarakat.

\section{PEMBAHASAN}

\section{Kondisi lingkungan di Desa Banyuwulu}

Desa Omben dan Le Pelle berada perbukitan dengan membelah perbukitan yang cukup terjal. Secara geopolitik wilayah desa Omben berada di wilayah Kecamatan Karang Pinang, Kabupaten Sampang dan Desa Le Pelle, Kecamatan Konang, Kabupaten Bangkalan, Jawa Timur Kecamatan Karang Pinang, Kabupaten Sampang dan Desa Le Pelle, Kecamatan Konang, Kabupaten Bangkalan, Jawa Timur namun secara etnisitas penduduk yang menempati mereka adalah berasal dari etnis Madura dan mempunyai ikatan cultural yang sangat kuat dengan kultur madura. Kondisi alam di kedua desa tersebut secara geografis kurang menguntungkan karena wilayahnya yang berada di puncak bukit. Sarana transportasi dan sarana komunikasi masih kurang memadai. Hal akan terlihat sangat parah pada saat musim kemarau. Tanah yang bergununggunung dengan struktur tanah yang mudah longsor dan bercampur batu menyebabkan tanah tidak dapat produktif sebagai lahan pertanian. Masyarakat lebih memilih tanaman ladang dan tanaman yang cocok untuk tegalan seperti ketela pohon, dan jagung. Pada wilayah-wilayah tertentu saja terutama yang dekat dengan sumber mata air akan ditanami tembakau. Sumber airpun sangat minim. Masyarakat mengandalkan kebutuhan air pada mata air sumber yang alirannya akan mengecil pada saat musim kemarau. Pemukiman di daerah menyebar dengan membentuk kelompok-kelompok kecil seperti pola pemukiman Kampong Meji pada masyarakat Madura. Kelompok- 
kelompok pemukiman menyebar yang biasanya akan membentuk kesatuan hidup berdasarkan pada ikatan kekerabatan yang berasal dari oreng dalam (saudara dengan ikatan kekeluargaan yang masih dekat dan ada hubungan darah) dan oreng loar (ikatan persaudaraan yang tidak ada hubungan darah secara langsung). Pola-pola pemukiman semacam ini sangat lazim di kedua desa Omben maupun Le Pellle.

Pola pemukiman di wilayah ke dua desa yaitu desa Omben dan Le Pelle secara umum terbagi menjadi dua yaitu pola kampong Meji dan pola Taneyan Lanjang. Teritori sebuah desa di Madura terdiri dari beberapa subdesa, yang terdiri dari beberapa kampong meji dan kampong meji terdiri dari beberapa keluarga. Desa-desa di Madura tinggal dalam kelompok-kelompok yang masing kelompok biasanya masih ada hubungan kekeluargaan. Kelompokkelompok pemukiman dalam sebuah desa antara satu dengan yang lainya saling terisolasi. Dengan pola pemukiman yang demikian inilah maka ikatan solidaritas desa ( sense of community ) di desa Omben maupun Le Pelle cenderung rendah dan sangat longgar. Ikatan solidaritas sosial akan sangat kuat pada kelompok-kelompok tempat tinggal yang terdiri dari beberapa keluarga yang masih ada hubungan genealogis.

Kampong Meji biasanya terdiri dari empat sampai delapan rumah . Rumah-rumah ini akan menghadap ke selatan. Deretan rumah-rumah dengan lahan yang sempit akan dibangun dengan formasi melingkar. Adanya solidaritas yang sangat kuat dalam kampong meji merupakan suatu bentuk kontrol sosial yang baik dalam sebuah kelompok masyarakat dimana angata satu anggota keluarga akan menjadi pengontrol bagi anggota yang lain. Sebagai contoh pada saat terjadi perseteruan individu dengan kelompok yang lain maka akan dimaknai sebagai perseteruan antar kelompok kampong meji.

Pola pemukiman yang lain yang dikenal masyarakat Maadura adalah pola taneyan lanjang. Taneyan lanjang merupakan satu unit sosial di Madura. Taneyan lanjang termasuk pekarangan besar dengan rumah-rumah yang dibuat berjajar dalam satu pekarangan yang memanjang. Kelompok-kelompok yang tinggal di taneyan lanjang adalah berasal dari satu kelompok geneologis, pasangan yang sudah menikah akan diharuskan untuk tinggal taneyan lanjang bersama dengan orang tua pihak perempuan dalam satu rumah yang khusus dibangun untuk anak-anak mereka.

Taneyan lanjang dibangun oleh keluarga-keluarga yang mempunyai keturunan dengan banyak anak dan berjenis kelamin perempuan. Sistem pola tempat tinggal taneyan lanjang mencerminkan kombinasi antara uxorilokal dan matrilokal atau uxorimatrilokal artinya anak perempuan yang sudah menikah akan tetap tinggal di pekarangan orang tuanya sementara anak laki-laki yang sudah menikah akan tinggal di pekarangan orang tua pihak istri atau mertua ( Latif.2002 : 42).

Selain pertimbangan banyaknya anak perempuan dalam satu keturunan, pola taneyan lanjang hanya dibangun oleh keluarga-keluarga yang mempunyai kemampuan secara ekonomis. Biasanya dalam satu taneyan lanjang terdiri lebih dari empat rumah dan tidak melebihi dari delapan rumah namun dalam beberapa taneyan lanjang ada yang lebih dari delapan 
rumah.Pola pemukiman taneyan lanjang di wilayah ke dua desa ini tidak banyak dijumpai, hanya beberapa seperti taneyan lanjang yang dimiliki oleh beberapa keluarga luas (dengan banyak anak perempuan) yang mampu di desa Omben dan Le Pelle

\section{Kedudukan wanita di Omben dan Le Pelle : Konstruksi Sistem Sosial dan Agama}

Peranan dan kedudukan wanita dalam kebudayaan yang berkembang di masyarakat Indonesia cenderung berpotensi untuk diperlakukan secara tidak adil. Masyarakat Indonesia yang mempunyai kecenderungan pada sistem patriarkhi menempatkan posisi wanita pada posisi di bawah kekuasaan lakilaki. Sistem patriarkhi memberikan andil yang besar terjadi adanya peminggiran peran wanita-wanita yang ada dalam masyarakat

Sistem patriarkhi secara umum menempatkan kedudukan wanita yang identik dengan hal-hal yang bersifat pelayanan domestik dan seorang wanita identik dengan segala hal yang bersifat feminim. Seorang wanita menanggung beban kerja domestik lebih banyak dan lebih lama (burden). Perempuan mengelola, menjaga dan memelihara kerapian, telah mengakibatkan tumbuhnya tradisi dan keyakinan masyarakat bahwa mereka harus bertanggungjawab dan terlaksananya keseluruhan pekerjaan domestik. Seorang wanita harus menyelesaikan tugas-tugas rumah tangga, mengatur rumah tangga dan juga tanggung jawab mendidik dan membesarkan anak. Beban itu akan semakin besar apabila seorang wanita juga bekerja di luar rumah.

Sebaliknya seorang laki-laki ditempatkan di atas wanita sebagai titik lawan dari peran wanita. Laki-laki pada posisi publik, maskulin, dan sebagai penentu kebijakan baik dalam rumah tangga maupun dalam lingkungan sosial masyarakat. Laki-laki tidak dibebani oleh tanggung jawab domestik, dan di beberapa tradisi masyarakat laki-laki dilarang untuk terlibat dalam pekerjaan domestik. Konsekuensi dari adanya penerapan sistem ini, di dalam masyarakat Madura interaksi sosial antara laki-laki dan perempuan yang ada digiring pada hubungan sosial yang dominasi oleh laki-laki dan wanita berada di bawah kekuasaan laki-laki.

Dominasi laki-laki Madura terhadap wanita-wanita Madura terjadi di dalam keluarga inti ( nuclear family ) maupun di dalam bentuk hubungan sosial masyarakat yang lebih luas. Dominasi dan peranan pokok dalam kehidupan masyarakat Madura menjadi laki-laki sebuah kekuatan kekuasaan penentu kebijakan domestik dalam keluarga maupun kebijakan publik dalam masyarakat. Wanita-wanita Madura dalam struktur masyarakat dikondisikan pada posisi domestik sekitar dapur dan mengurus anak dan pelayan keluarga. Sebaliknya laki-laki Madura berada di depan dan menguasai peranan publik yang banyak berhubungan dengan dunia luar dan penentu kebijakan, dunia luar seakanakan menjadi wilayah maskulin dari masyarakat Madura.

Seorang laki-laki Madura akan menempatkan diri sebagai pelindung dan penjaga martabat wanita-wanita yang ada di bawah " kekuasaannya". Sistem dan struktur masyarakat Madura mengkondisikan wanitawanitannya mempunyai hubungan ketergantungan yang besar terhadap laki-laki. Wanita dikondisi dalam 
struktur sosial dalam posisi yang lemah, sedang laki-laki sebaliknya.

Proteksi yang kuat pada wanitawanita Madura seringkali dirasakan sebagai suatu bentuk ketertindasan hak wanita-wanita. Proteksi terhadap wanita-wanita Madura sering dibarengi dengan sikap yang berlebihan dari lakilai madura dengan prasangka terhadap kemungkinan-kemungkinan terjadinya penyelewengan dan pelecehan terhadap wanita.

Bagi seorang laki-laki ungkapan harga diri terdapat dalam konsep "malo" (malu) dan juga konsep pada masyarakat Madura yang dijadikan dasar dalam segala aspek kehidupan adalah ango'an poteya tolang etembang poteya mata (lebih baik mati dari pada menanggu malu). Pusat dari malo diletakkkan pada wanita-wanita Madura.

Proteksi yang kuat pada wanitawanita Madura dan peranan yang sangat dominan dari laki-laki Madura akan menggiring pada pembatasanpembatasan ruang gerak dari wanitawanita Madura. Peminggiran ruang gerak wanita-wanita Madura mengakibatkan marginalisasi (pemiskinan ) sosial dalam arti terjadi adanya penekanan peran sosial dari wanita-wanita Madura, demikian juga marginalisasi ekonomi ( pemiskinan ) secara ekonomi serta marginalisasi peranan politiknya.

Marginalisasi peranan wanita Madura juga didukung oleh sistem sosial yang ada yang terkecil yaitu keluarga. Keluarga inti maupun keluarga luas. Salah satu bentuk marginalisasi wanita yang dilakukan oleh laki-laki dan masyarakat secara umum di Madura tercermin dalam pola-pola pemukiman masyarakat Madura.. Proteksi dalam pola rumah orang-orang Madura lebih diarahkan pada keberadaan ruang gerak wanita-wanita Madura.

Stratifikasi sosial didasarkan pada pemahaman agama. Stratifikasi sosial ini penting untuk dikaji karena akan sangat berkaitan dengan pola pikir dari budaya Madura seperti pada penduduk Omben maupun Le Pelle yang masih memegang erat budaya Madura dan masih sangat terpengaruh oleh keberadaan Agama dalam hal ini agama Islam. Stratifikasi sosial berdasarkan pada agama terdiri dari dua penggolongan yaitu santre (santri) dan banne santre (bukan santri). Dalam kelompok santre akan dirinci lagi dalam tiga kelompok yaitu pertama, Keyae (kiai) yaitu kelompok orang-orang yang dikenal sebagai pemuka agama karena menguasai ilmu agama Islam. Kelompok keyae sebagai pembina umat yang mengajarkan ilmuilmu agama dan biasanya mempunyai kemampuan supranatural, mereka biasanya mempunyai lembaga pendidikan agama berupa pesantren. Selain itu Bindarah dianggap sebagai kelompok menengah dibawah Keyae. Ketiga adalah santre, kelompok ini terdiri dari orang-orang yang menjadi murid atau sedang belajar agama.

Penduduk desa Omben dan Le Pelle merupakan masyarakat yang banyak terpengaruh oleh ajaran agama Islam. Seperti yang dikemukakan oleh Fakih bahwa agama dapat mempengaruhi terhadap sistem nilainilai yang ada dan berkembang di dalam suatu masyarakat. Masyarakat desa Omben maupun desa Le Pellle melihat keberadaan gender di tempat berdampingan erat dengan pengamalan agama Islam. Masyarakat desa Omben maupun desa Le Pellle melihat sistem patriarkhi yang ada dalam praktek kehidupan sehari-hari dicampurkan dengan ajaran-ajaran Islam yang 
menempatkan posisi laki-laki sebagai kelompok yang lebih tinggi dan dominan. Keberadaan laki-laki yang lebih tinggi dari perempuan seolah-olah membentuk adanya stratifikasi sosial tersendiri meskipun mungkin terlalu dini untuk menyimpulkan stratifikasi ini.

Stratifikasi ini didukung oleh ajaran agama yang digunakan untuk mengukuhkan keberadaan posisi lakilaki dalam masyarakat dan mendeskritkan perempuan sebagai kelompok yang ada di bawah laki-laki. Penggambaran seperti ini membentuk adanya pemahaman yang semu seolaholeh kekuasaan laki-laki sebagai suatu kekuasaan pemuka agama yang katakatanya sering kali sebagai sebuah dogma yang tak terbantahkan. Sebagai contoh adalah sikap penghormatan seorang wanita pada laki-laki dalam berkomunikasi. Seorang wanita harus abasa menggunakan bahasa yang halus dan menggunakan bahasa yang baik dan digunakan untuk menghormati orangorang yang dianggap mempunyai status sosial yang tinggi. Sebaliknya seorang laki-laki akan mapas (tidak menggunakan bahasa halus untuk penghormatan pada wanita). Laki-laki akan mapas (menggunakan bahasa kasar) jika berkomunikasi dengan seorang wanita.

Dengan demikian secara terstruktur masyarakat Madura sudah membiasakan para wanita untuk menerima perbedaan status antara lakilaki dan perempuan (gender) sebagai sebuah pengakuan terhadap sistem yang sudah selayaknya, seharusnya diterima oleh para wanita Madura. Berkaitan dengan permasalah dalam penelitian ini, penggunaan bahasa abasa oleh kaum perempuan terhadap suami atau laki-laki memberikan pembatasan-pembatasan seorang wanita Madura untuk mengekspresikan keinginan, perasaannya dan mungkin tindakannya. Seorang wanita yang ingin mengekspresikan kemarahnnya, tidak terekspresikan lewat bahasa karena pembatasan etika dan sopan santun yang terkandung dalam penggunaan bahasa tersebut. Sebaliknya seorang laki-laki biasanya akan menggunakan bahasa mapas dalam berkomunikasi dengan istri atau para wanita pada umumnya. Menurut Siegel bahasa mapas memberikan kebebasan dalam berkomunikasi secara leluasa untuk mengungkapkan keinginan, perasaan, yang tergambaran dalam penggunaan dan pemilihan kata yang lebih banyak dan ekspresif.

Laki-laki secara hirarkis berada di atas perempuan karena penefsiran agama menganggap demikian. Asumsi teologis dan dikembangkan menjadi asumsi budaya yang sering memojokkan perempuan dengan pernyataan bahwa Hawa diciptakan untuk memenuhi hasrat laki-laki, Hawa diciptakan dari tulang rusuk Adam, Adam terjerumus karena Hawa.

Kedudukan wanita di Madura layaknya seperti yang digambarkan dalam tafsir agama tersebut. Apabila kita kembali pada masyarakat Madura yang cenderung fanatik dan menerima apa ajaran agama seperti apa yang dikatakan oleh pemimpinan agama sebagai kebenaran yang mutlak. Dogma agama yang terbentuk karena penghormatan yang besar terhadap status keyae. Pada saat seorang keyae mengajarkan dogma tersebut secara otomatis menjadi nilai sosial yang harus ditaati oleh para wanita Madura.

Pemaknaan simbol-simbol status sosial berdasarkan gender yang ada pada masyarakat Madura diwujudkan dengan adanya gender difference adalah 
sebagai hasil pemaknaan simbol-simbol sosial dengan konstruk agama. Perempuan desa Omben maupun Le Pellle terpojokan dalam kehidupan masyarakat sedang laki-laki berperanan sebagai figur yang berkuasa dan sangat dominan. Seorang wanita Madura harus patuh kepada laki-laki (suami) dengan menyamakan kepatuhan mereka pada apa yang dikatakan oleh seorang ulama (keyae).

Penggambaran kepatuhan seorang perempuan (istri ) pada saat peneliti berada di tengah-tengah masyarakat Madura. Ketika program Keluarga Berencana masuk di desa-desa seorang bidan desa mengeluh karena sulitnya mendapatkan aseptor yang mau ikut serta dalam program tersebut. Apa yang dikeluhkan oleh Bidan disaksikan sendiri oleh peneliti di kedua desa tersebut, seorang wanita yang sebenarnya mau mengikuti program Keluarga Berencana tetapi akhirnya memutuskan tidak ikut karena dilarang oleh suami yang katanya tidak boleh oleh keyae anutannya. Kasus ini tidak hanya dijumpai oleh satu dua orang saja tetapi rata-rata wanita-wanita desa lebih menuruti apa yang dikatakan oleh suami dari pada menuntut hak sebagai perempuan.

Agama seringkali disalahgunakan sebagai alat untuk mengontrol tingkah laku dan sikap serta tindakan-tindakan yang akan diambil untuk mengesahkan pelanggaran-pelanggaran hak asasi perempuan. Hal inilah yang mengakibatkan adanya ketidakadilan dalam kehidupan wanita-wanita Madura.

Peranan sentral yang dimiliki oleh seorang ulama dalam membentuk suatu wacana yang akan diberikan pada masyarakat sangat dominan. Namun berbeda dengan kedudukan seorang pemuka agama baik Keyae, bindarah, dan para santre, mereka adalah kelompok-kelompok pemimpin informal tetapi mempunyai kekuasaan riil, mempunyai pengikut yang setia dan loyal.

Guru agama, ulama dan lembaga-lembaga pendidikan Islam seperti madrasah , pesantren memmpunyai andil yang besar didalam membentuk wacana perempuan sebagai kelompok sosial masyarakat yang terpinggirkan oleh keberadaan nilai-nilai budaya dan agama. Sebagai salah satu contoh konkrit yang ada di pesantrenpesantren di Madura di ajarkan tentang bagaimana seharusnya seorang wanita dan bagaimana posisi wanita yang terdapat dalam kitab Adabu Al- Mar'ah (kitab tentang etika pempuan). Kitab ini diajarkan untuk para santri wanita sebagai pegangan dan dijadikan sebagai rujukan untuk wanita-wanita Madura secara umum. Kitab ini mengajarkan bagaimana seorang wanita yang "ideal “ antara berisi tentang hak dan kewajiban seorang wanita, peranan wanita sebagai ibu terhadap pengasuhan anak, dimana hak asuh dan tanggungjawabnya dibebankan pada seorang istri (wanita dalam keluarga); wanita juga dibebani untuk menjaga martabat keluarga seolah-olah wania sebagai pusat dari terjadinya penyelewengan sehingga harus mampu menjaga martabatnya; seorang wanita juga sebagai penjaga harta laki-laki dan penata rumah tangga. Dalam kitab itu seolah-olah wanita banyak sekali beban tanggungjawab dalam lingkungan domestik.

Kitab Adabu Al Mar'ah yang berisi tentang kewajiban perempuan yang harus mengabdi dan patuh pada suami, mendidik anak dan menjaga kehormatan keluarga semua mengarah 
pada bagaimana seharusnya seorang wanita meskipun dirasa kurang seimbang. Hak-hak perempuan dan istri dalam kitab tersebut tidak dikupas.

Pesantren dan lembaga agama lainnya yang ada di Madura mensubordinasi dan memarginalisasi perempuan Madura. Aktivitas perempuan-perempuan Madura sebagai sebuah refleksi dari pemahaman sikap dan tingkah laku yang didasari oleh pemikiran "Good will Keyae". Pemahaman ini akan diterapkan dalam sebuah lingkup yang lebih kecil yaitu dalam sebuah keluarga. Penempatan seorang suami sebagai pemimpin keluarga menjadikan kedudukannya disamakan dengan kedudukan seorang pemimpin agama yang harus dipatuhi dan dihormati Good will husband.

Seorang wanita yang melangsungkan pernikahan akan diberi mahar. Mahar ( mas kawin ) pada Masyarakat Madura merupakan sebuah simbol yang dimaknai dengan kepemilikan. Makna yang muncul dari sebuah simbol mahar ( mas kawin ) ditafsirkan oleh ulama syafiiyah yang berkembang pada masyarakat Madura baik yang ada diwilayah Madura atau orang-orang Madura diluar wilayah Madura seperti halnya yang ada di kedua desa Omben dan Le Pelle. Makna yang diberikan pada simbol mahar ( mas kawin) sebagai bentuk kepemilikan hak bagi seorang laki-laki untuk mengambil manfaat sexual, pelayaan keseharian seorang laki-laki Madura atas wanita-wanita yang dinikahinya. Pendapat ini secara kaku diikuti oleh guru-guru agama, sehingga pendapatpendapat di luar syafiiyah di abaikan . Demikian juga tentang mahar, bagi orang Madura mahar dimaknai sebagai pembelian atas kepemilikan sebuah benda atau barang. Wanita yang sudah menikah dengan seorang laki-laki dinggap menjadi milik dari seorang suami dan seorang suami mempunyai hak atas perempuan.

Sebuah contoh dalam proses sosialisasi nilai-nilai patriarkhi pada masyarakat desa Omben maupun Le Pellle disosialisasikan sejak dini pada diri anak laki-laki dengan memberi pengajaran yang lebih pada laki-laki, misalnya seorang laki-laki boleh melanjutkan studi setelah lulus dari pesantren atau Madrasah tetapi untuk anak-anak perempuan kesempatan untuk mengenyam pendidikan sangat dibatasi dan ada anggapan bahwa seorang wanita tidak memerlukan pendidikan yang tinggi, karena yang diperlukan oleh seorang wanita adalah pengetahuan sebagai rumah tangga dan pelayanan yang baik dalam keluarga.

Domestiksasi perempuan dengan wacana yang ditanamkan pada sosok wanita ideal seperti istri pendamping suami, ibu harus meladeni suami, dan anak-anak, keluarga masyarakat dan negara. Domestiksasi perempuan menunjukan adanya dominasi kekuasaan patriarkhi. Perbedaan gender yang dikontruksi secara sosial selalu dilakukan melalui berbagai institusi termasuk di dalamnya institusi keluarga, dimana sosialisasi dan internalisasi terjadi. Sebuah keluaga menjadi media sosialisasi nilai-nilai yang berkembang dalam masyarakat.

Menurut Foucault kekuasaan tidak dapat dilokalisasi . kekuasaan merupakan suatu tatanan disiplin dan dihubungkan dengan jaringan, memberikan struktur kegiatan tidak representatif tetapi produktif serta melekat pada kehendak. Untuk mengetahui kekuasaan ini menurut Foucoult diwujudkan cerita-cerita yang 
turun temurun,guru, guru agama atau oleh lembaga yang sengaja dibentuk.

\section{Latar Belakang pendidikan masyarakat Desa Omben dan Le Pelle}

Penduduk desa Omben maupun

Le Pellle mempunyai latar belakang pendidikan yang sangat minim. Ada dua katagori pendidikan yang berkembang di desa tersebut yaitu pendidikan formal sekolah negeri dan pendidikan informal yaitu pendidikan yang di dapat dari pendidikan agama, seperti pesantren dan juga pengajian dilanggar atau masjid.

Jumlah sekolah dasar yang ada di desa ini rata-tara sebanyak 2 buah dalam hal ini perlu dibedakan lagi bahwa satu sekolah di daerah Krajan dan satunya lagi di Arak-Arak. Dari dua sekolah dasar yang ada yang berjalan lancar artinya proses belajar mengajar mulai hari Senin sampai Sabtu hanya satu yaitu sekolah dasar yang berada di Krajan sedangkan sekolah dasar yang ada di Arak-Arak hanya hari-hari tertentu saja dibuka itupun sangat tergantung pada kesediaan guru yang bersedia berangkat ke sekolah Krajan. Secara efektif sekolah dasar Krajan sajalah yang dapat dikatakan sekolah yang sebenarnya.

Penduduk desa mempunyai kecenderungan memasukan anak-anak usia sekolah mereka ke pesantrenpesantren di kecamatan ataupun di wilayah Madura dan wilayah Situbondo dan Jember. Prosentase anak usia sekolah yang sekolah di sekolah dasar dan pesantren tidak ada data kuantitatif namun apabila kita lihat dari perbandingan sekolah dasar yang ada maka anak-anak pada usia sekolah ratarata mendapat pendidikan informal baik dari pesantren atau dari langgar dan masjid.
Sebagai suatu gambaran pendidikan yang ada di desa Omben dapat dilihat dari petikan peristiwa pada saat penulis melihat adanya perkawinan muda yang dilakukan oleh anak perempuan yang baru kelas tiga sekolah dasar. Pada saat penulis menanyakan hal ini kepada ibu dari si anak calon pengantin alasan pernikahan muda ibu tersebut menjawab:

“sengkok takut Yam ta' paju lake' mon ta' kawin dina' Ning. Be'nyak nak-kanak kinik kawin.. (artinya Saya takut Yam tidak laku pria (tidak ada pria yang mau mengambil istri) kalau tidak menikah sekarang Mbak. Banyak anakanak kecil menikah.."

Pada kenyataan di lapangan jumlah anak perempuan yang bersekolah lebih sedikit dibandingkan dengan anak laki-laki. Anak-laki-laki akan diberi kebebasan untuk melanjutkan paling tingkat sampai setingkat dengan SLTP namun kebanyakan dari anak-anak laki-laki melanjutkan ke sekolah setingkat dengan Madrasah Tsanawiyah, yang berada di kecamatan kecamatan. Di ke dua desa tersebut tidak tersedia Madrasah baik Ibtidaiyah, Tsnawiyah maupun Aliyah. Dengan demikian sarana pendidikan dalam masyarakat belumlah mencukupi. Sepanjang pengetahuan dari penulis anak yang dikirim oleh orang tuanya untuk menuntut ilmu di Madrasah Ibtidaiyah dan Tsnawiyah masih dapat dihitung dengan jari. Anak laki-laki lebih banyak digiring ke ladang setelah mereka mengenyam bangku sekolah dasar ataupun pesantren. Kalaupun mereka masih di pesantren mereka rata-rata sebagai santri saja tanpa menginjak jenjang pendidikan formal. Anak-anak perempuan jarang yang dikirim ke pesantren. Kecenderungan untuk 
menempatkan mereka ke ruang-ruang domestik di dalam rumah.

\section{Kondisi Ekonomi Masyarakat Desa Omben maupun Le Pellle}

Penulis tidak mendasarkan dari pengamatan kwantitatif sehingga dalam hal ini penulis hanya mendasarkan pada kepemilikan dari rumah yang ada di desa ke dua desa Omben maupun Le Pellle. Kondisi rumah rata-rata menggunakan bahan bambu dan kayu, serta atap jerami (welit). Ada beberapa rumah yang menggunakan kayu dan berlantai semen namun hanya orangorang yang "dianggap kaya" dan mempunyai ladang yang cukup saja. Kelompok ini seperti kepala desa, carik dan ada beberapa orang yang "dihormati" secara social seperti ulama yang rata-rata mereka sudah menjalankan ibadah haji.

Masyarakat rata-rata sebagai petani peladang dan buruh ladang. Sebagai suatu gambaran tentang kondisi ekonomi tentang pemahaman "mayarakat gunung” atau " oreng gunung" tentang sistem pertukaran uang. Penulis pernah menjumpai seorang gunung yang membawa tempayan, tempat air, yang dibuat dari tanah, pada saat berbincang bincang orang tersebut belum begitu paham dengan uang dan ini merupakan hal yang bagi penulis suatu kemustahilan pada abad XXI dan era globalisasi. Namun itulah kenyataan ada di lapangan di mana masih dijumpai adanya masyarakat yang tidak familier dengan sistem tukar dengan uang tetapi lebih suka dengan sistem barter dan pedagang tersebut meminta pada penulis untuk menukar dengan beras, dan lauk ikan asin.

Kondisi ekonomi juga dilihat dari konsumsi makanan oleh masyarakat secara umum. Masyarakat desa Omben maupun Le Pellle lebih banyak mengkonsumsi ketela dan jagung sebagai pengganti beras. Di desa tersebut tidak jumpai pasar desa, mereka akan ke pasar pada saat harihari pasaran dan letak pasar berada di kecamatan yang harus ditempuh dengan berjalan kaki selama 1,5 jam atau menggunakan sepeda motor buntut - Mereka seringkali makan seadanya, bahkan ada kebiasaan dari masyarakat untuk mengkonsumsi sejenis unthuk (sejenis hewan yang muncul dari kotoran kerbau yang sengaja dibuat oleh orang-orang di desa tersebut dengan menggali lubang dan menimbun kotoran tersebut dan dibiarkan beberapa hari), hewan tersebut dikatakan dibuat sebagai lauk pengganti daging.

\section{Perspektif Pemerintah Terhadap Program Keluarga Berencana}

Pengertian Keluarga Berencana menurut perpsektif pemerintah yang diintegralkan dalam Pelita I yaitu untuk menurunkan angka fertilitas . Dalam pengertian ini Keluarga Berencana bukan sebagai pembatasan kelahiran tetapi sebagai upaya untuk mengatur kelahiran . Dengan demikian Keluarga Berencana lebih ditempatkan sebagai upaya controlling terhadap tingkat fertilitas yang terjadi dalam masyarakat. Program Keluarga Berencana difokuskan pada pada pasangan usia subur (PUS). sedangkan alat kontrasepsi yang ada meliputi pil, IUD (Intra Uterine Device), CD (Condoom), Suntik, Susuk KB (Masri,1992: 25) 
Analisa perspektif Masyarakat Desa Omben maupun Le Pellle terhadap Program Keluarga Berencana

Pada suatu pagi seorang bidan desa datang penulis dan mengatakan untuk meminta bantuan untuk ikut mendatangi rumah-rumah untuk menerangkan arti pentingnya Keluarga Berencana. Bidan tersebut sebenarnnya sudah berkali-kali mendatangi rumahrumah yang ada pasangan usia subur (PUS) namun selalu gagal untuk dapat menyetukan pemahaman tentang apa itu Keluarga Berencana.

Usaha menyebarkan dan memahamkan masyarakat tentang program ini sebenarnya sudah berkalikali juga dilakukan di Kelurahan atau Dukuh-Dukuh tetapi tetap saja peserta Keluarga Berencana tidak muncul secara sadar untuk ikut dalam program tersebut.

Ada sebuah pengalaman yang mungkin dapat memberikan sebuah gambaran tentang perspektif masyarakat dalam penerimaan program tersebut dari sikap pada saat penulis dan bidan desa berkeliling bertandang ke rumah-rumah warga ternyata sebagian dari rumah yang didatangi selalu sepi dan berkali-kali diketuk tidak dibukakan. Meskipun ada dugaan kuat mereka ada di rumah, namun bukan permasalahan tidak mau menerima tamu tetapi mereka sudah dapat menduga bahwa Bidan desa akan mengingatkan dan menganjurkan masuk dalam program Keluarga Berencana.

Pemasalahan mulai dapat penulis ketahui dengan lebih jelas ketika sebuah rumah terbuka dan kami sempat bertamu dan Bidan desa menjelaskan tentang program $\mathrm{KB}$, namun hal yang cukup mengejutkan adalah jawaban dari seorang ibu yang kami datangi bahwa dia menyetakan " engkok tak oleh mbe' Apa mon KB, Ning, Pak Kyae ta' oleh (saya tidak boleh ikut KB oleh Bapak dan juga pak Kyai). Dari jawaban itu maka penulis dapat melihat adanya sebuah struktur masyarkat yang sangat didominasi seorang suami dan juga dominasai seorang ulama sebagai rujukan dalam bertindak termasuk dalam hal ini permasalahan keluarga berencana. Apabila kita merujuk dengan sistem social yang berkembang di masyarakat Madura yang lebih menempatkan laki-laki dengan lebih dominan hal ini tentunya sangat dapat dimengerti.

Pada saat penulis menanyakan tentang Keluarga Berencana banyak jawaban yang pada intinya mereka mengetahui Keluarga Berencana sebagai suatu hal untuk menghambat kelahiran, namun ada juga yang menjawab bahwa KB sebagai program pemerintah untuk tidak melahirkan. Dari dua jawaban ini sebenarnya mempunyai dua perpspektif yang berbeda yang pertama lebih melihat sebagai usaha manusia untuk mengatur adanya kelahiran dan jawaban pertama ini rata-rata diberikan oleh istreri-isteri dari pejabat desa. Jawaban kedua lebih mengarah pada pandangan yang negatif bahwa program KB untuk mnyebabkan tidak melahirkan yang mengandung arti bias dari masyarakat sebagai upaya menolak pemberian anak dari Allah dan lebih ekstrim lagi sebagai upaya untuk "membunuh " janin dalam kandungan. Jawaban kedua rata-rata dari laki-laki dan sebagian wanita dengan alasan lain yaitu "kata pak kyai, atau pak haji" dan indikasi ini akan mengarahkan kita pada adanya dominasi kelompok kyai dalam masyarkat yang sangat mempengaruhi 
terhadap perspektif masyarakat terhadap program KB tersebut.

\section{Perspektif Masyarkat Terhadap Alat Kontrasepsi dan adanya Marginalisasi wanita}

Masyarakat mengetahui beberapa alat kontrasepsi yatg bias mereka gunakan antara lain Suntik, IUD, condom, pil, susuk. Pada masayrakat yang sudah melakukan $\mathrm{KB}$ rata rata menggunakan Pil KB sebagai pilahan yang banyak dilakukan dengan alasan hal tersebut tidak bertentangan dengan ajaran agama dan boleh oleh suami. Hal yang paling ditolak adalah IUD dan susuk dengan lasan bahwa IUD berarti membunuh janin dan susuk sama saja.

Pemahaman tentang pembunuhan janin setelah ditanyakan jawabannya banyak merujuk pada " perkataan kyai " dan tidak boleh oleh suami. Selain itu orang Madura lebih suka melakukan KB sendiri dengan jamu (yang dibuat dari ramuan dari merica dan juga kapur yang sudah direndam beberapa bulan dan dibuat jamu) atau mereka lebih suka dengan KB alamiah dan KB tanggal. Pemakaian alat kontrasepsi dianggap" tidak baik " menurut agama dan "suami".

Dominasi suara laki-laki dalam menentukan pilihan yang harus dilakukan oleh seorang wanita Madura merupakan bentuk peminggiran hakhak wanita untuk menentukan pilihan. Hal ini tentunya akan berimplikasi pada adanya bias gender. Keberadaan kyai sebagai panutan dan nrujukan dalam bertindak dalam masyarakat juga tidak lepas dari adanya sistem masyarakat yang menempatkan status ulama sebagai kelompok social yang sangat dominan dan tinggi. Dengan demikian adanya hubungan yang secara langsung maupun tidak, sistem budaya sangat berpengaruh terhadap pola-pola yang muncul dalam suatu masyarakat.

\section{Kesimpulan}

Program Keluarga berencana sebagai program pemerintah dalam upaya untuk mengatur fertilasi tidak sepenuhnya berhasil terutama bila berhadapan dengan adanya perspektif yang berbeda di dalam memandang keberadaan dari program Keluarga Berencana ersebut.

Di desa Omben maupun Le Pellle program Keluarga Berencana kurang berhasil. Hal ini tidak semata-mata disebabkan oleh kelemahan dari program tersebut ataupun pelaksanaan teknis di lapangan yang tidak menyentuh pada masyarkat tetapi ada hal yang lain yang perlu diperhatikan dalam mensikapi permasalahan Keluarga Berencana di desa ini. Pendekatan etnosains ternyata mampu memberikan suatu gambaran yang berbeda untuk melihat mengapa program tersebut tidak dapat diterima. Pemahaman tentang Keluarga Berencana pada masyarakat desa Omben maupun Le Pellle lebih diartikan sebagai bentuk pembatasan kelahiran bahkan dalam konteks yang berbeda dalam pemahaman agama adalah upaya pembunuhan dini terhadap janin.

Pemahaman yang berbeda terutama sangat dipengaruhi oleh budaya yang ada yang lebih di dasarkan pada ajaran Islam dengan menempatkan figur-figur tokoh agama sebagai tokoh peran yang menentukan pola-pola tingkah laku dan sikap masyarakat .

Sasaran program pada PUS akan melibatkan peran wanita (istri) dan lakilaki (suami) dalam menentukan keberhasilan program ini. Dalam masyarakat yang mempunyai 
kecenderungan patriarkhi dengan menempatkan posisi laki-laki lebih kuat dan dominan menyebabkan peran wanita di desa ini cenderung termajinalisasi. Berkaitan dengan program ini maka keputusan untuk ikut atau tidak seorang wanita (istri) dalam program ini sangat ditentukan oleh suami.

\section{DAFTAR PUSTAKA}

Bashin, Kamla. 2001. Memahami Gender Telaah Keislaman atas $\begin{array}{llllll}N & a & s & k & a & h\end{array}$ Simboer Tjahya. Jakarta: Millenium.

Clifford, J. and Mercus, G.E. (edt.). 1986. Writing Culture: The Poetics and Polities of Etnography. Berkeley: Univercity of California Press.

Darwin, Muhadjir. 2001. Membongkar Budaya Patriarkhi. Jakarta: Graffity Press.

De Jong, Huub. 1989. Agama, Budaya dan Ekonomi (Studi-studi Interdisiliner tentang Masyarakat Madura . Yogyakarta. Rajawali press.

Dillistone, F.W. 2002. The Power of Symbols.Yogyakarta: Kanisius.

Engineer, Asghar Ali. 2005. Pembebasan Perempuan. Jakarta ; Lkis.

Fakih, Mansour. 1996. Analisis Gender dan Tranformasi Sosial. Yogyakarta:Pustaka Pelajar.

Heddy Shri Ahimsa-Putra.. " Ethnoart: Fenomenologi Seni Untuk Indiginasi Seni dan Ilmu, dalam Waridi.2005. Menimbang Pendekatan Pengkajian dan
Penciptaan Musik Nusantara (cet .I) Bandung.STIS press.

Heropoetri, Arimbi. 2004. Percakapan tentang Feminisme Vs Neoteralisme.Jakarta: Debtwach Ind.

Koentjoroningrat. 1990. Sejarah Teori Antropologi. Jakarta: Universitas Indonesia Press.

Lie, Shirley. 2005. Pembebasan Tubuh Perempuan. Jakarta: Grasindo.

Murniati, Nunuk P. 2005. Getar Gender jilid I. jakarta: Indonesia Tera.

Proyek Penelitian Madura. 1977.Keluarga Berencana dan Kesehatan di Pulau Madura. Depdikbud.

Singarimbun, Masri.1988 Keluarga Berencana Indonesia sampai Abad XXI: Beberapa Aspek Program Dan Sosial Budaya. Jakarta: tp. . 2001. Perubahan Sosial dalam Masyarakat Agraris Madura. Yogyakarta: Mata Bangsa. . 1990. Keluarga

Berencana. Yogyakarta:PAU UGM. .1993. Keluarga Berencana di Sriharjo: AspekAspek Sosial Budaya dan Program. Yogyakarta: Pusat Penelitian Gadjah Mada.

Wiyata, A. Latif. 2002. Carok (Konflik Kekerasan dan Harga Diri Orang Madura . Yogyakarta: Lkis. 
Sumber surat kabar Jawa Pos, 19 januari 2003. Kompas, 27 Juni 2005. Kompas, 8 Aguatus 2005.

Kompas, 28 Oktober 2005 